\title{
COUNTING SPERMA AKTIF MENGGUNAKAN METODE OTSU THRESHOLD DAN LOCAL ADAPTIVE THRESHOLD
}

\author{
Moch. Hatta ${ }^{1}$, I Gde Susrama ${ }^{2}$ \\ 1Teknik Komputer, Fakultas Teknik \\ Universitas Maarif Hasyim Latif, Sidoarjo, Indonesia \\ e-mail : moch.hatta@dosen.umaha.ac.id \\ ${ }^{2}$ Teknik Informatika, Fakultas Ilmu Komputer \\ Universitas Pembangunan Nasional "VETERAN" Jawa Timur, Surabaya, Indonesia \\ e-mail : gdesusrama@gmail.com
}

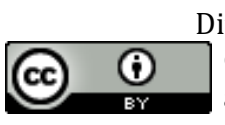

Diterima: 27 Maret 2017. Disetujui : 21 Mei 2017. Dipublikasikan : 1 Juni 2017

(C)2017 -TESJ Fakultas Teknik Universitas Maarif Hasyim Latif. Ini adalah artikel dengan akses terbuka di bawah lisensi CC BY 4.0 (https://creativecommons.org/licenses/by/4.0/)

\begin{abstract}
ABSTRAK
Analisis sperma adalah pemeriksaan awal yang dilakukan pada kasus infertilitas pria, salah satunya adalah menentukan motiliti normal dan abnormal, yang dilakukan oleh ahli. Analisa sperma ini juga dapat dilakukan secara otomatis dengan berbantuan komputer, yaitu dengan cara mengambil per-frame video sperma kemudian dilakukan proses segmentasi. Pada proses segmentasi terdapat beberapa kendala antara lain data video yang diambil mempunyai intensitas yang berbeda, sehingga diperlukan beberapa metode segmentasi. Penelitian ini adalah membandingkan proses Otsu Threshold dan proses Local Adaptive Threshold (LAT), dengan proses preprosessing yang menggunakan segmentasi Otsu dan Local Adaptive, sehingga dari beberapa data frame video sperma yang disegmentasi akan diketahui segmentasi yang harus digunakan. Dari hasil penelitian didapatkan bahwa intensitas cahaya pada frame sperma yang dianalisis merata, dapat digunakan Otsu Threshold dan jika gambar sperma yang dianalisis intensitasnya tidak merata akan lebih bangus menggunakan Local Adaptive Threshold, dengan demikian untuk melakukan ekstraksi fitur lebih bagus, namun dari beberapa frame (bingkai) sperma yang diujicoba secara acak didapatkan akurasi yang lebih menggunakan proses otsu threshold yaitu $82 \%$ dibandingkan dengan menggunakan proses local adaptive threshold yaitu hanya $52 \%$.
\end{abstract}

Kata kunci : local adaptive threshold (LAT), morphologi, motiliti, otsu, segmentasi, sperma

\section{PENDAHULUAN}

Proses analisa sperma secara otomatis salah satunya adalah melakukan proses segmentasi video sperma yang didapat dari mikroskop melalui kamera. Hasil penangkapan video kamera tidak seutuhnya mendapatkan gambar yang intensitas cahaya nya yang merata, terkadang antara latar belakang dan gambar sperma mempunyai intensitas yang sama.

Segmentasi spermatozoa dapat dilakukan dengan menggunakan metode Marker-Controlled Watershed Segmentation (Abbiramy, 2010), penggunaan metode segmentasi tersebut karena gambar yang digunakan adalah data yang berasal dari data publik, sehingga metode segmentasi apapun yang digunakan akan menghasilkan gambar tersegmentasi yang baik.

Demikian juga pada proses binarisasi gambar, dilakukan proses pemisahan nilai-nilai pixel menjadi dua kelompok, putih sebagai latar belakang dan hitam sebagai latar depan (Singh, 2012). Jadi Thresholding memainkan utama dalam binarisasi gambar. (Singh, 2012) dibandingkan antara thresholding global dan thresholding lokal, data gambar yang dipakai ada beberapa salah satunya adalah gambar dokumen, dengan distribusi kontras seragam latar belakang dan latar depan, sehingga dikatakan thresholding global yang lebih tepat. Kemudian dilakukan lagi segmentasi terhadap gambar dokumen terdegradasi, di mana intensitas latar belakang yang cukup atau variasi dalam kontras dan pencahayaan ada, terdapat banyak piksel yang tidak dapat dengan mudah diklasifikasikan sebagai latar depan atau latar belakang. Dalam kasus tersebut, binarisasi dengan thresholding lokal lebih tepat.

Penelitian lainnya berkaitan dengan segmentasi adalah pada aplikasi perhitungan jumlah sel darah putih (Nemane, 2013) dengan menggunakan Metode Global Threshold. Pada makalahnya dikemukakan bahwa pemisahan inti sel darah putih dengan latar belakang yang ada dilakukan proses segmentasi, data gambar sel darah putih diambil kemudian dilakukan proses Grey Scale Image dengan menggunakan automatic 


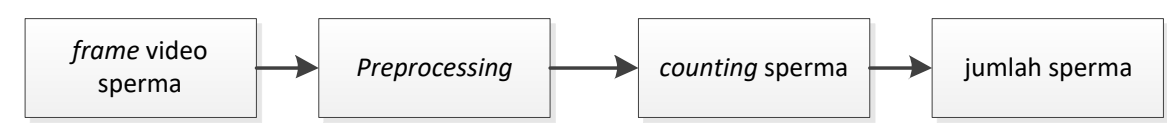

Gambar 1. Desain sistem untuk menghitung jumlah sperma per frame video

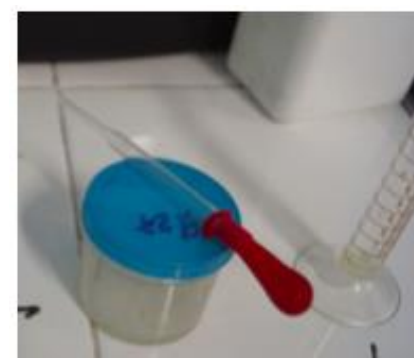

(a)

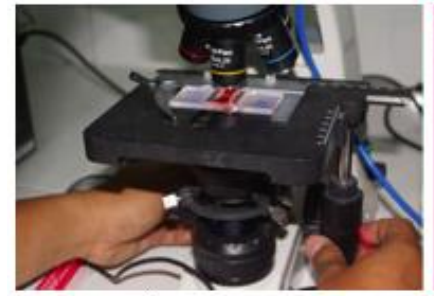

(d)

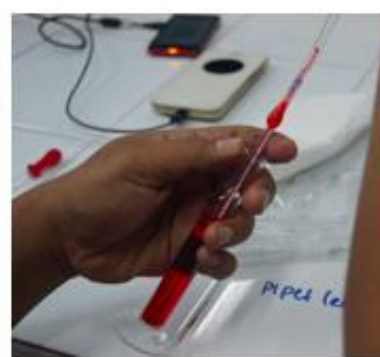

(b)

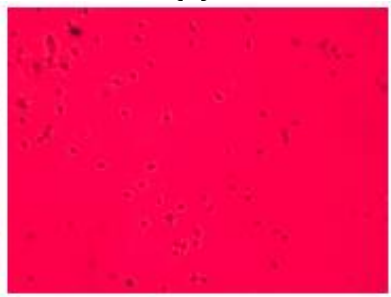

(e)

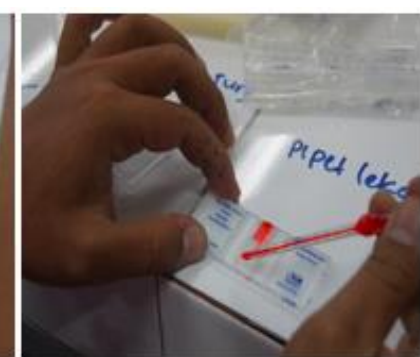

(c)

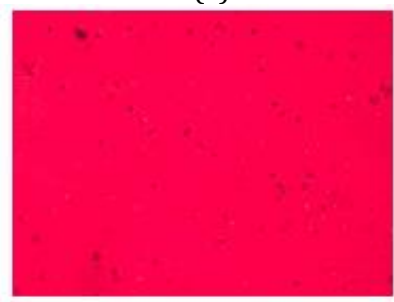

(f)

Gambar 2.(a) Sperma yang akan dilakukan tes, (b) Proses pencampuran dengan larutan eosin $0.5 \%$ dan diaduk rata, (c) Diteteskan pada kamar hitung neubauer, (d) Dilihat pada mikroskop, (e) dan (f), Hasil penangkapan sperma pada kamera.

contrast stretching (Adjust Image Intensity dan Histogram Equalization), proses selanjutnya adalah operasi aritmatika, proses penyaring (filtering) dan teknik threshold global sehingga mampu untuk men-segmentasi citra sel darah dan menghitungnya.

Geometri tangan merupakan salah satu jenis biometrik yang sering digunakan dalam sistem autentikasi (Putra, 2004). Proses binerisasi citra tangan, penentuan nilai ambang untuk proses binerisasi menggunakan metode Otsu. Metode ini menentukan nilai ambang dengan menggunakan analisis driskriminan. Citra input adalah citra tangan gray level 256 warna dengan latar belakang berwarna hitam. Berdasarkan hasil uji coba yang dilakukan, metode Otsu mampu memberikan hasil citra tangan biner yang sangat memuaskan. Untuk melihat keberhasilan tersebut, pada tulisan ini juga disertakan perbandingan hasil proses binerisasi dengan menggunakan aplikasi pengolah gambar.

Dari beberapa penelitian terdahulu, beberapa proses segmentasi dengan menggunakan berbagai metode sudah dilakukan, dengan kesimpulan bahwa metode segmentasi global threshold (Metode Otsu) dengan metode segmentasi Local Adaptive Threshold dapat digunakan sesuai dengan kebutuhan citra atau gambar yang akan disegmentasi. Pada makalah ini akan dibahas penerapan metode otsu dan adaptif local threshold pada segmentasi morphologi sperma, dengan tujuan untuk mendapatkan hasil terbaik dari bentuk atau morphologi sperma, karena data yang didapat dari mikroskop digital tidak semuanya bagus.

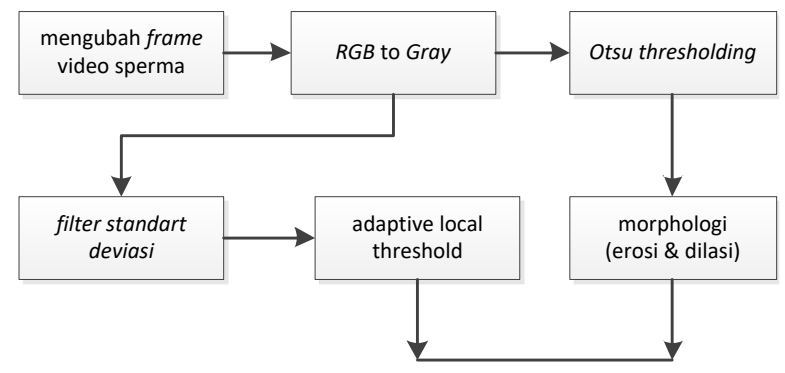

Gambar 3. Proses pre-processing analisa sperma

\section{METODE PENELITIAN}

Tahapan-tahapan dari metode yang diusulkan untuk melakukan segmentasi sperma ditunjukkan pada Gambar 1.

\section{Frame Video Sperma}

Data Sperma yang digunakan adalah data dari salah satu pasien yang melakukan tes kesuburan di laboratorium Poltekes Surabaya. Sesuai dengan prosedur tes sperma standar WHO 2010, sperma diambil langsung dari pasien setelah melakukan ejakulasi 10-20 menit. Kemudian sperma yang sudah likuifaksi, diproses, seperti Gambar 2, sehingga didapatkan video sperma.

\section{Pre-Processing}


Preprosesing adalah proses pengolahan data asli sebelum data tersebut (frame video sperma) diolah (proses labelisasi dan hitung sperma). Tujuan dari proses ini adalah untuk menghilangkan noise, memperjelas features (fitur) data, memperkecil/memperbesar ukuran data, mengkonversi data asli agar diperoleh data sesuai dengan kebutuhan. Pada Gambar 3, ditunjukan proses pre-prosesing analisa sperma.

\section{RGB to Gray}

Merupakan citra digital yang hanya memiliki satu nilai kanal pada setiap pikselnya, artinya nilai dari Red $=$ Green $=$ Blue. Nilai-nilai tersebut digunakan untuk menunjukkan intensitas warna [11]. Citra yang ditampilkan dari citra jenis ini terdiri atas warna abu-abu, bervariasi pada warna hitam pada bagian yang intensitas terlemah dan warna putih pada intensitas terkuat.

Citra grayscale berbeda dengan citra hitamputih, dimana pada konteks komputer, citra hitam putih hanya terdiri atas 2 warna saja yaitu hitam dan putih saja. Pada citra grayscale warna bervariasi antara hitam dan putih, tetapi variasi warna diantaranya sangat banyak. Citra grayscale seringkali merupakan perhitungan dari intensitas cahaya pada setiap piksel pada spektrum elektromagnetik single band

Citra grayscale disimpan dalam format 8 bit untuk setiap sampel piksel, yang memungkinkan sebanyak 256 intensitas. Untuk mengubah citra berwarna yang mempunyai nilai matrik masingmasing $R, G$ dan $B$ menjadi citra grayscale dengan nilai $X$, maka konversi dapat dilakukan dengan mengambil rata-rata dari nilai $R, G$ dan $B$ sehingga dapat dituliskan menjadi persamaan (1) dan persamaan (2).

$$
\begin{gathered}
X=\frac{R+G+B}{3} \\
\text { Warna }=R G B(X, X, X)
\end{gathered}
$$

\section{Citra Biner}

Citra biner (binary image) adalah citra digital yang hanya memiliki 2 kemungkinan warna, yaitu hitam dan putih. Citra biner disebut juga dengan citra W\&B (White \& Black) atau citra monokrom. Hanya dibutuhkan 1 bit untuk mewakili nilai setiap piksel dari citra biner. Pembentukan citra biner memerlukan nilai batas keabuan yang akan digunakan sebagai nilai patokan. Piksel dengan derajat keabuan lebih besar dari nilai batas akan diberi nilai 1 dan sebaliknya piksel dengan derajat keabuan lebih kecil dari nilai batas akan diberi nilai 0 .

Citra biner sering sekali muncul sebagai hasil dari proses pengolahan, seperti segmentasi, pengambangan, morfologi ataupun dithering. Fungsi dari binerisasi sendiri adalah untuk mempermudah proses pengenalan pola, karena pola akan lebih mudah terdeteksi pada citra yang mengandung lebih sedikit warna. Persamaan untuk binerisasi dapat dilihat pada rumus persamaan (3).

$$
f(x, y)=\left\{\begin{array}{l}
a_{1}, f(x, y)<T \\
a_{2}, f(x, y) \geq T
\end{array}\right.
$$

nilai $a_{1}$ biasanya 0 dan nilai $a_{2}=1$

\section{Otsu Threshold}

Thresholding citra merupakan suatu teknik yang banyak digunakan untuk segmentasi, yaitu membagi citra gray level ke segmen yang sesuai untuk beberapa kelas berdasarkan nilai gray level. Pendekatan thresholding kebanyakan diusulkan untuk dua kelas, dan didasarkan pada histogram gray level dari citra. Dalam penelitian ini thresholding tidak digunakan untuk segmentasi citra sebagai tujuan akhir, tetapi sebagai titik acuan dalam memaksimalkan kontras untuk pembedaan background dan foreground sebesar-besarnya. Threshold membagi area ke dalam dua kelas sebagai berikut :

$$
g(x, y)=\left\{\begin{array}{ll}
0 & f(x, y)<T \\
1 & f(x, y) \geq T
\end{array}\right\}
$$

Tujuan dari metode Otsu adalah untuk menemukan titik threshold yang membagi histogram citra gray level ke dalam dua daerah yang berbeda secara otomatis, di mana titik yang dipilih adalah sedemikian sehingga inter-class variance adalah sebesar mungkin. Tujuan tersebut dicapai dengan meminimalkan bobot within-class variance, yang sebenarnya adalah sama dengan : memaksimalkan inter-class variance. Persamaan (5) menampilkan rumus bobot dari within-class variance.

$$
\sigma_{w}^{2}(t)=q_{1}(t) \sigma_{1}^{2}(t)+q_{2}(t) \sigma_{2}^{2}(t)
$$

dengan : $\sigma_{w}^{2}(t)$ : total within-class variance, $\sigma_{1}^{2}(t)$ : within-class variance dari kelas pertama, $\sigma_{2}^{2}(t)$ : within-class variance dari kelas kedua, $q_{1}(t)$ : class probabilities dari kelas pertama, $q_{2}(t)$ : class probabilities dari kelas kedua $t$ : nilai gray level yaitu nilai threshold. Class probablilites dari kelas pertama dan kedua adalah (di mana $i$ mewakili jumlah kemunculan piksel untuk gray-level tertentu, sedangkan $t$ adalah nilai gray level). Within-class variance dari masing-masing kelas ditampilkan di persamaan (6) dan persamaan (7).

$$
\begin{gathered}
\sigma_{1}^{2}(t)=\sum_{i=1}^{t}\left[i-\mu_{1}(t)\right]^{2} \frac{P(i)}{q_{1}(t)} \\
\sigma_{2}^{2}(t)=\sum_{i=1}^{t}\left[i-\mu_{2}(t)\right]^{2} \frac{P(i)}{q_{2}(t)}
\end{gathered}
$$


Jika dihitung semua nilai $\sigma_{1}^{2}(t)$ dan $\sigma_{2}^{2}(t)$ pada citra gray scale maka akan diperoleh nilai within-class variance minimum. Nilai $t$ yang membuat $\sigma_{1}^{2}(t)$ dan $\sigma_{2}^{2}(t)$ menjadi minimum adalah nilai threshold yang dicari. Namun proses komputasi dapat dihemat dengan memanfaatkan fakta bahwa total variance pada suatu image adalah selalu konstan, tidak bergantung pada nilai threshold. Sehingga untuk sebarang threshold $t$, total variance adalah jumlah dari within-class variance dan inter-class variance diperoleh dengan persamaan (8).

$$
\sigma^{2}=\underbrace{\sigma_{w}^{2}(t)}_{\text {withinclas s variance }}+\underbrace{q_{1}(t)\left[1-q_{1}(t]\left[\mu_{1}(t)-\mu_{2}(t)\right]^{2}\right.}_{\text {interclass variance }=\sigma_{B}^{2}(t)}
$$

Berikut adalah pseudo code untuk menghitung nilai $\sigma_{\omega}^{2}(t)$ pada persamaan (5) untuk melakukan proses threshold pada frame video sperma adalah sebagai berikut :

1. Menghitung histogram dan probabilitas dari tiap level intensitas (yaitu normalisasi dari histogram tersebut sehingga totalnya adalah sama dengan satu )

2. Set nilai awal $q_{1}(t), q_{2}(t)$ dan $\mu_{1}(t), \mu_{2}(t)$

3. Menjajaki seluruh nilai threshold yang mungkin $t$ $=1 \ldots$ maximum intensity

a. Update nilai $q_{1}(t), q_{2}(t)$ dan $\mu_{1}(t), \mu_{2}(t)$

b. Hitung $\sigma_{\omega}^{2}(t)$

4. Threshold yang dicari adalah yang memberikan maksimum $\sigma_{\omega}^{2}(t)$.

\section{Morphologi (Dilasi dan Erosi)}

Morphologi adalah teknik pengolahan citra digital dengan menggunakan bentuk (shape)

sebagai pedoman dalam pengolahan. Nilai dari setiap pixel dalam citra digital hasil diperoleh melalui proses perbandingan antara pixel yang bersesuaian pada citra digital masukan dengan pixel tetangganya. Operasi morphologi bergantung pada urutan kemunculan dari pixel, tidak memperhatikan nilai numeric dari pixel sehingga teknik morphologi sesuai apabila digunakan untuk melakukan pengolahan binary image dan grayscale image. Dengan mengatur atau memilih ukuran dan bentuk dari matrik kernel (structuring element) yang digunakan maka kita dapat mengatur sensitivitas operasi morphologi terhadap bentuk tertentu (spesifik) pada citra digital masukan. Operasi morphologi standar yang dilakukan adalah proses erosi dan dilasi. Dilasi adalah proses penambahan pixel pada batas dari suatu objek pada citra digital masukan, sedangkan erosi adalah proses pemindahan/pengurangan pixel pada batas dari suatu objek. Jumlah pixel yang ditambahkan atau yang dihilangkan dari batas objek pada citra digital masukan tergantung pada ukuran dan bentuk dari structuring element yang digunakan.

Dilasi adalah operasi morphologi yang akan menambahkan pixel pada batas antar objek dalam suatu citra digital. Operasi ini menggunakan aturan sebagai berikut: "Untuk gambar grayscale maka nilai hasil operasi (output pixel) adalah nilai maksimal yang diperoleh dari himpunan pixel tetangganya. Dalam binary image, jika ada pixel tetangga yang bernilai 1 maka output pixel akan diset menjadi $1 "$.

Erosi adalah operasi morphologi yang akan mengurangi pixel pada batas antar objek dalam suatu citra digital. Operasi ini menggunakan aturan sebagai berikut: "Untuk gambar grayscale maka
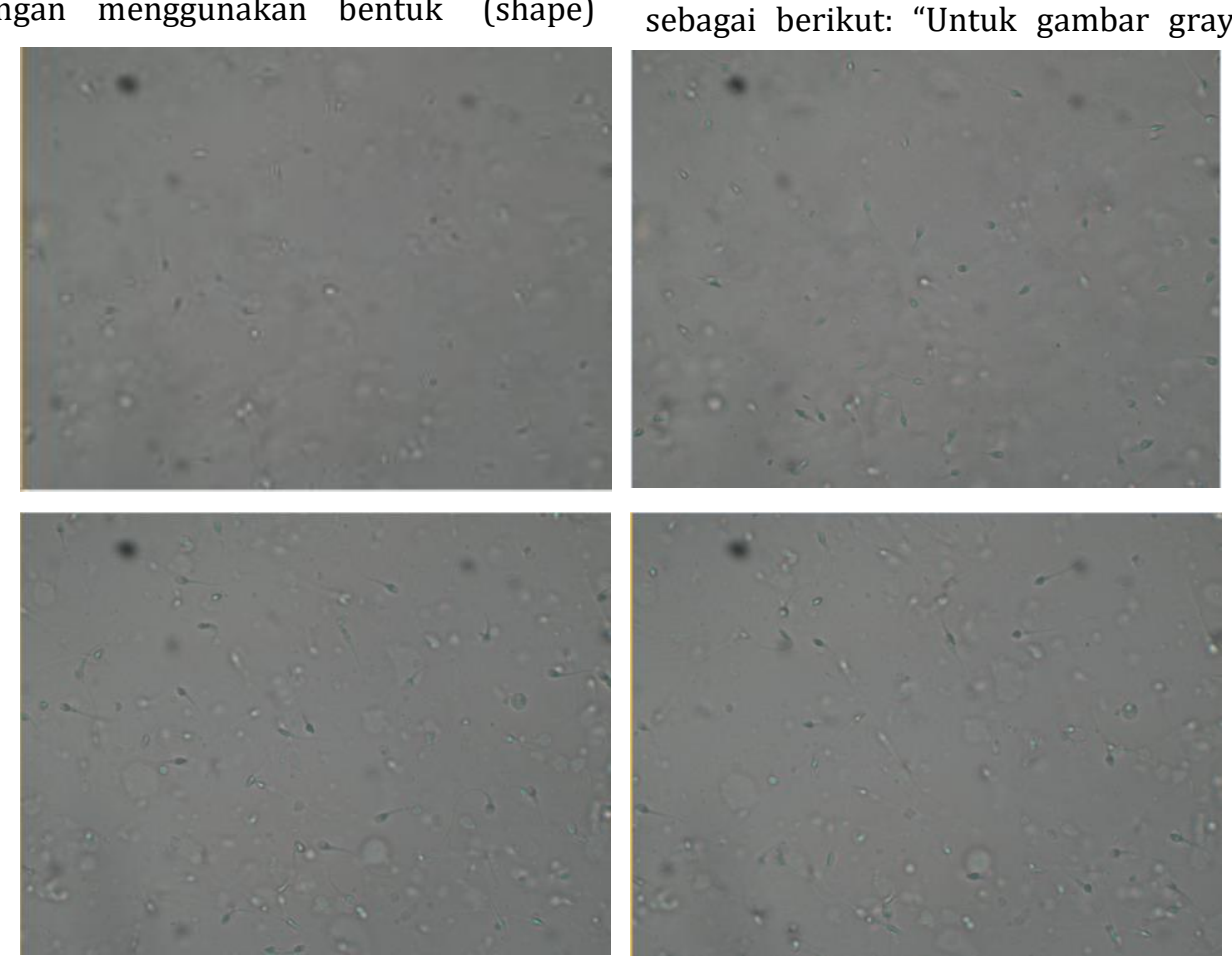

Gambar 4. Contoh frame sperma yang diproses 
nilai hasil operasi (output pixel) adalah nilai minimal yang diperoleh dari himpunan pixeltetangganya. Dalam binary image, jika ada pixel tetangga yang bernilai 0 maka output pixel akan diset menjadi 0 ".

\section{HASIL DAN PEMBAHASAN}

Hasil penerapan dari analisa sperma ini dapat dijabarkan sebagai berikut ;

1. Data sperma yang digunakan video sperma salah satu pasien yang real. Data video sperma tersebut diolah dan diambil frame per frame sebanyak 100 frame sperma. Contoh sperma yang digunakan dapat dilihat pada Gambar 4 .

2. Kemudian dilakukan proses pre-prosesing. Pada proses ini dilakukan konversi frame menjadi gambar grayscale, proses dilanjutkan dengan menghilangkan noise. Dalam proses ini digunakan mean filter, karena memberikan hasil yang lebih baik dibandingkan dengan filter median.

3. Langkah selanjutnya adalah mengubah frame menjadi gambar biner, dan disegmentasi menggunakan otsu threshold.

4. Proses selanjutnya mencoba menerapkan beberapa metode untuk melakukan proses ini. Dari proses (3) di atas akan dibandingkan hasil menggunkan Local Adaptive Threshold dengan menggunakan morphologi. Hasil perbandingan dapat dilihat pada Gambar 5

Gambar 5 (a) adalah data frame video sperma yang diambil dan yang akan diujicoba, pada gambar asli terlihat bahwa tidak hanya sel sperma saja yang tertangkap, namun juga leukosit atau yang lainnya selain sperma, yang berupa gumpalan putih atau hitam dalam frame, gumpalan-gumpalan tersebut dapat menutupi gambar sperma yang asli dan sperma tidak dapat tertangkap dibeberapa bagian, sehingga data tersebut kadang dapat dikatakan sperma tapi kadang tidak terbaca sebagai sperma, dan inilah salah satu dari kekurangan sistem.

Hasil segmentasi dengan menggunakan otsu threshold, tidak cocok digunakan pada citra yang memiliki persebaran warna yang hampir sama. Pada Gambar 5.(a) Citra didominasi oleh warna abu-abu yang memiliki nilai yang sama dengan warna sel sperma, sehingga lebih sulit untuk mengenali sperma. Dari hasil segmentasi dengan menggunakan Metode otsu threshold dapat dilihat pada Gambar 5 (b). Metode Otsu baik untuk menemukan batas tunggal dan memisahkan warna sperma tunggal dari latar belakang. Tetapi, background dan sel sperma memiliki warna yang hampir sama. Warna air mani juga memiliki varian yang tinggi, sehingga proses otsu threshold dilanjutkan dengan membandingkan antara menggunakan proses morphologi dan dengan menggunakan Local Adaptive Threshold, hasilnya dapat dilihat pada Tabel 1.

5. Adaptive local threshold memberikan hasil yang lebih baik (Gambar 5 (c)) karena disesuaikan di setiap kernel m x m untuk setiap daerah. Namun demikian, metode ini memberikan penampilan sperma tebal yang berguna untuk memisah sel sperma dengan latar belakang. Metode yang digunakan mempunyai sifat adaptif yang meliputi nilai rata-rata lokal, standar deviasi lokal dan standar deviasi global. Hasil segmentasi dengan menggunakan Local Adaptive

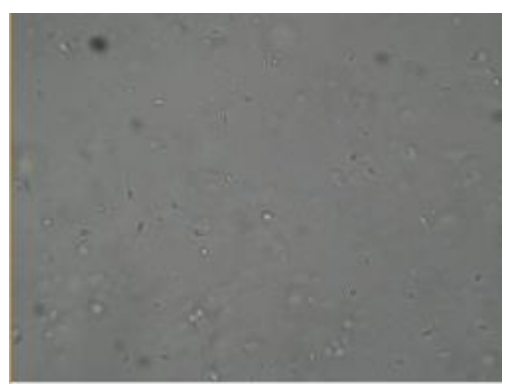

(a)

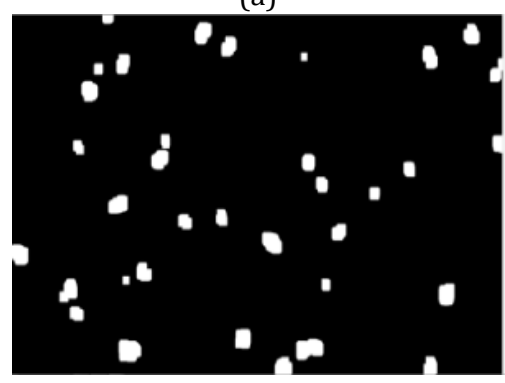

(d)

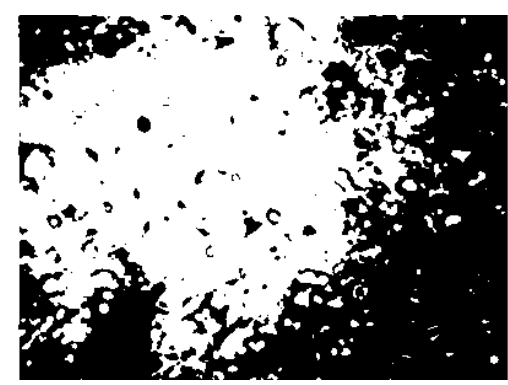

(b)

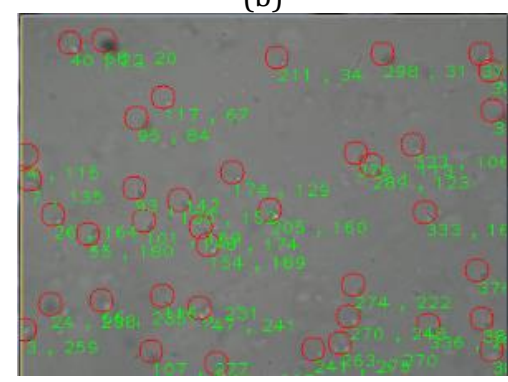

(e)

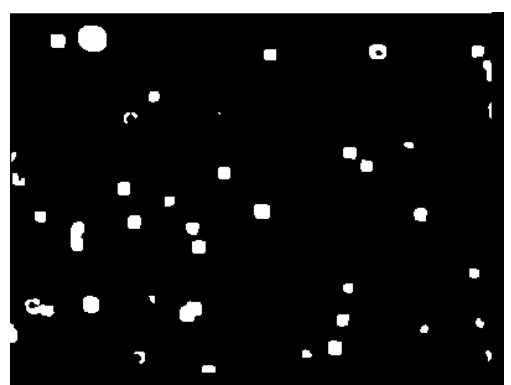

(c)

Gambar 5. (a) frame sperma (b) hasil otsu threshold (c) hasil local adaptive threshold (d) hasil dengan proses morphologi 
Tabel 1. Hasil uji coba hitung sperma manual dan sistem

\begin{tabular}{|c|c|c|c|c|c|c|c|c|c|c|c|}
\hline \multirow[b]{2}{*}{ Video/ frame } & \multirow{2}{*}{$\begin{array}{c}\text { Jumlah } \\
\text { spermatozoa } \\
\text { hitungan } \\
\text { manual }\end{array}$} & \multicolumn{5}{|c|}{ Otsu Threshold } & \multicolumn{5}{|c|}{ Local Adaptive Threshold } \\
\hline & & $T P$ & $\boldsymbol{F P}$ & $F N$ & $T N$ & $\frac{T P}{M}(\%)$ & $T P$ & $\boldsymbol{F P}$ & $F N$ & $T N$ & $\frac{T P}{M}(\%)$ \\
\hline Real1-Frame1 & 49 & 41 & 2 & 10 & N/A & 84 & 45 & 22 & 4 & $N / A$ & 92 \\
\hline Real1-Frame4 & 58 & 48 & 0 & 10 & $N / A$ & 83 & 2 & 1 & 56 & $N / A$ & 3 \\
\hline Real1-Frame7 & 53 & 45 & 3 & 11 & $N / A$ & 85 & 3 & 3 & 50 & $N / A$ & 6 \\
\hline Real1-Frame15 & 64 & 58 & 3 & 9 & $N / A$ & 91 & 18 & 4 & 46 & $N / A$ & 28 \\
\hline Real1-Frame28 & 52 & 41 & 1 & 12 & $N / A$ & 79 & 5 & 3 & 47 & $N / A$ & 10 \\
\hline Real2-Frame1 & 63 & 39 & 2 & 26 & $N / A$ & 62 & 35 & 62 & 28 & $N / A$ & 56 \\
\hline Real2-Frame4 & 71 & 62 & 0 & 9 & N/A & 87 & 60 & 33 & 11 & $N / A$ & 85 \\
\hline Real2-Frame7 & 67 & 58 & 1 & 10 & $N / A$ & 87 & 53 & 20 & 14 & $N / A$ & 79 \\
\hline Real2-Frame15 & 37 & 26 & 2 & 13 & $N / A$ & 70 & 25 & 57 & 12 & $N / A$ & 68 \\
\hline \multirow[t]{2}{*}{ Real2-Frame28 } & 53 & 50 & 1 & 4 & $N / A$ & 94 & 47 & 57 & 6 & $N / A$ & 89 \\
\hline & & \multicolumn{4}{|c|}{ Rata-rata } & 82 & \multicolumn{4}{|c|}{ Rata-rata } & 52 \\
\hline
\end{tabular}

Threshold dapat dilihat pada Tabel 1, terlihat bahwa rata-rata frame video sperma yang diujicobakan, hasil pembacaan secara manual dan sistem masih banyak ketidak sesuaian, sehingga rata-rata errornya adalah $52 \%$

6. Lain halnya hasil proses dengan menggunakan proses hasil otsu threshold pada Gambar 5(d), terlihat bahwa rata-rata frame video sperma yang diujicobakan, hasil pembacaan secara manual dan sistem masih banyak sesuai, sehingga rata-rata errornya adalah $82 \%$

7. Hasil rata-rata diatas (52\% dan $82 \%$ ) secara sistem didapat setelah citra terpisah maka dilakukan penghitungan kontur dari (Gambar 5 (c) dan 5 (d)). Dicari nilai kumpulan piksel yang bernilai lebih besar dari 25 piksel. Dari pencarian 25 piksel didapat posisi sperma dan jumlah sperma seperti (Gambar 5 (e)). Menemukan ambang error dengan melakukan ujicoba kurang begitu efektif karena dari hasilnya tidak merepresentasikan karakter dari sperma.

\section{PENUTUP}

Untuk melakukan segmentasi citra sperma menggunakan metode otsu, tidak mendapatkan hasil segmentasi yang bagus. Dikarenakan citra sperma dengan background memiliki nilai warna yang hampir sama. Sehingga metode otsu yang menghitung persebaran seluruh citra, tidak cocok digunakan

Metode Local Adaptive Threshold cocok digunakan sebagai ambang batas pada citra yang memiliki kerapatan nilai yang hampir sama. Dari hasil yang didapat citra sperma sudah terpisah dengan background walaupun beda nilai warnanya hampir sama. Namun citra lain seperti debu juga tertangkap

Dari beberapa frame (bingkai) sperma yang diujicoba secara acak didapatkan akurasi yang lebih menggunakan proses otsu threshold yaitu
82\% dibandingkan dengan menggunakan proses Local Adaptive Threshold yaitu hanya 52\%.

Dari hasil segmentasi tersebut sudah dapat ditentukan posisi sperma serta banyaknya sperma yang dapat dihitung dengan metode kontur namun masih banyak noise yang tertangkap seperti debu ataupun sel leukemia pada mikroskop

\section{DAFTAR PUSTAKA}

Abbiramy, V. S., \& Shanthi, V. (2010). Spermatozoa segmentation and morphological parameter analysis based detection of teratozoospermia. International Journal of Computer Applications, 3(7), 19-23.

Hatta, M. (2016). Penentuan Abnormalitas Pergerakan Spermatozoa Manusia Berbasis Regresi Linier (Tesis, Institut Teknologi Sepuluh Nopember. Teknik Elektro).

Hatta, M., Susrama, I. G., Edi Purnama, I. K., \& Hariadi, M. (2016). CACAH SPERMATOZOA MENGGUNAKAN BACKGROUND SEGMENTATION DAN BOUNDARY DETECTION. SCAN-Jurnal Teknologi Informasi dan Komunikasi, 11(1), 67-74.

Hidayatullah, P., \& Zuhdi, M. (2014, November). Automatic sperms counting using adaptive local threshold and ellipse detection. In Information Technology Systems and Innovation (ICITSI), 2014 International Conference on (pp. 56-61). IEEE.

Kaula, N., Andrews, A., Durso, C., Dixon, C., \& Graham, J. K. (2009, September). Classification of hyperactivated spermatozoa using a robust Minimum Bounding Square Ratio algorithm. In Engineering in Medicine and Biology Society, 2009. EMBC 2009. Annual International Conference of the IEEE (pp. 4941-4944). IEEE.

Maini, R., \& Aggarwal, H. (2010). A comprehensive review of image enhancement techniques. arXiv preprint arXiv:1003.4053. 
Nemane, J. B., Chakkarwar, V. A., \& Lahoti, P. B. (2013). White blood cell segmentation and counting using global threshold. International Journal of Emerging Technology and Advanced Engineering, 3(6), 639-643.

Otsu, N. (1979). A threshold selection method from gray-level histograms. IEEE transactions on systems, man, and cybernetics, 9(1), 62-66.

Press, W. H. O. (2010). Laboratory manual for the examination and processing of human semen. World Health Organization, Geneva,
7-113.

Putra, I. K. G. (2004). Binerisasi Citra Tangan dengan Metode Otsu.Majalah Ilmiah Teknologi Elektro, 3(2).

Rizal, A. (2014). Instrumentasi Biomedis. Yogyakarta: Graha Ilmu.

Singh, T. R., Roy, S., Singh, O. I., Sinam, T., \& Singh, K. (2012). A new local adaptive thresholding technique in binarization. arXiv preprint arXiv:1201.5227. 
M Hatta, dkk / Teknika, Vol. 1, No.1, Juni 2017, 47-54

Halaman ini sengaja dikosongkan 